\title{
CORRESPONDENCE
}

\section{Absence of SARS-CoV-2 RNA in COVID-19-associated intestinal endothelialitis}

\author{
Klaus Stahl $1^{*}$ (D) Jan Hinrich Bräsen ${ }^{2}$, Marius M. Hoeper ${ }^{3}$ and Sascha David ${ }^{4}$
}

(c) 2021 Springer-Verlag GmbH Germany, part of Springer Nature

Recent reports that SARS-CoV-2 virus particles could be visualized by electron microscopy (EM) in endothelial cells of various organs [1] gave rise to the hypothesis that endothelial injury and micro-thrombosis, which are central elements of coronavirus disease 2019 (COVID-19) pathophysiology [2], might be a consequence of direct endothelial cell infection by SARS-CoV-2. However, these observations have been challenged, as intracellular structures such as the endoplasmatic reticulum (ER) may mimic SARS-CoV-2 particles on EM [3].

In a recent issue of Intensive Care Medicine, we published images of the resected colon of a COVID19 patient presenting with non-occlusive mesenteric ischemia (NOMI). The specimens demonstrated severe endothelialitis and EM showed intracellular structures resembling SARS-CoV-2 [4].

The present discussion regarding potential false positive EM findings with regard to SARS-CoV-2 drove us to re-examine our specimens. For this purpose, we established an in situ hybridization technique (SARS-CoV-2 Hulu-FISH probe, MetaSystems). The technique was confirmed using lung tissue from a deceased COVID-19 patient as a positive control (Fig. 1a). Interestingly, the gut endothelium from our original patient was indeed negative for SARS-CoV-2 RNA (Fig. 1b, c). We therefore believe that the Corona-like structures shown by EM in our patient are "morphological look-alikes" of genuine corona viruses (including coated vesicles, multi-vesicular bodies and cross-sections of the rough ER) [5].

Nevertheless, the development of NOMI in severe COVID-19 [1, 4] together with the histological

*Correspondence: stahl.klaus@mh-hannover.de

${ }^{1}$ Department of Gastroenterology, Hepatology and Endocrinology, Medical School Hannover, Hannover, Germany

Full author information is available at the end of the article
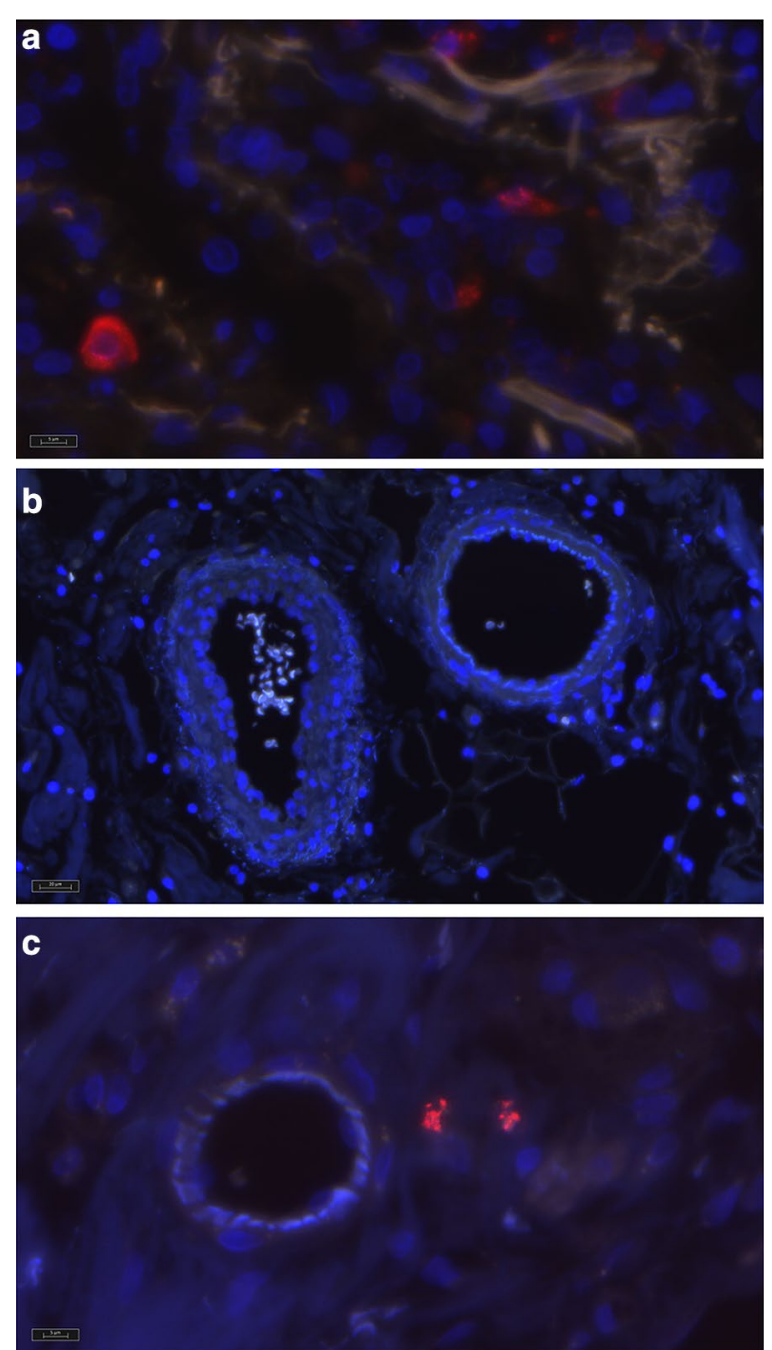

Fig. 1 Fluorescent in situ hybridization using RNA-SARS-CoV-2 HuluFISH PLUS probe tagged with Atto565 (MetaSystems Probes, Altlussheim, Germany). Abundant positive signals can be seen in lung specimen of a patient who died from Covid-19 pneumonia (red signals, a). In the gut specimens of our patient, vessels including those with severe endothelialitis were completely negative $(\mathbf{b})$; only single signals in cells located within interstitium can be seen (c) (micrographs by courtesy of Jessica Schmitz, Nephropathology Unit, Institute of Pathology, MHH) 
demonstration of massive intestinal endothelialitis and microvascular thrombosis is of high clinical relevance for intensivists fighting COVID-19. Evidently, some patients with severe COVID-19 develop a systemic vasculitis, the pathogenesis of which is not yet understood but might be triggered by indirect effects rather than direct viral infection.

\section{Author details}

${ }_{1}^{1}$ Department of Gastroenterology, Hepatology and Endocrinology, Medical School Hannover, Hannover, Germany. ${ }^{2}$ Institute of Pathology, Medical

School Hannover, Hannover, Germany. ${ }^{3}$ Department of Respiratory Medicine and German Centre of Lung Research (DZL), Medical School Hannover, Hannover, Germany. ${ }^{4}$ Institute for Intensive Care Medicine, University Hospital Zurich, Zurich, Switzerland.

\section{Compliance with ethical standards}

\section{Conflicts of interest}

On behalf of all authors, the corresponding author states that there is no conflict of interest.

\section{Publisher's Note}

Springer Nature remains neutral with regard to jurisdictional claims in published maps and institutional affiliations.
Accepted: 23 November 2020

Published online: 3 January 2021

\section{References}

1. Varga Z, Flammer AJ, Steiger $P$, Haberecker $M$, Andermatt $R$, Zinkernagel AS, Mehra MR, Schuepbach RA, Ruschitzka F, Moch H (2020) Endothelial cell infection and endotheliitis in COVID-19. Lancet 395:1417-1418

2. Ackermann M, Verleden SE, Kuehnel M, Haverich A, Welte T, Laenger F, Vanstapel A, Werlein C, Stark H, Tzankov A, Li WW, Li VW, Mentzer SJ, Jonigk D (2020) Pulmonary vascular endothelialitis, thrombosis, and angiogenesis in Covid-19. New England J Med 383:120-128

3. Goldsmith CS, Miller SE, Martines RB, Bullock HA, Zaki SR (2020) Electron microscopy of SARS-CoV-2: a challenging task. Lancet 395:e99

4. Stahl K, Bräsen JH, Hoeper MM, David S (2020) Direct evidence of SARSCoV-2 in gut endothelium. Intensive Care Med 23:1-2

5. Hopfer H, Herzig MC, Gosert R, Menter T, Hench J, Tzankov A, Hirsch HH, Miller SE (2020) Hunting coronavirus by transmission electron microscopy - a guide to SARS-CoV-2-associated ultrastructural pathology in COVID-19 tissues. Histopathology 125:39-46 